\title{
Religious education and teaching young people about humanity: Suggesting a new role for RE and for the academic study of religions in Sweden
}

\author{
JONAS SVENSSON \\ Linnæus University
}

\begin{abstract}
This article is a suggestion for the rethinking of the role and purpose of religious education (RE) in Swedish public schools, in relation to two major recent reforms: of teachers training (2012) and of syllabi for RE (2011). Based on a notion of the 'humanistic' study of religions as he study of religion as a human cultural product, the article argues that a RE - mainly in lower and upper secondary school - informed by contemporary theoretical development, better than any other school subject can cater for the important task of educating young people about who they, as human beings, are and why. To substantiate this claim, the content of the above mentioned reforms are presented, and placed in historical context. Furthermore, the article provides a set of examples of how actual teaching may be structured to fulfil its proposed new task, with a basis in the current syllabi for lower and upper secondary school.
\end{abstract}

Keywords: humanistic study of religions, religious education, Sweden, syllabi, educational reforms, didactics of religion

In 2011 the Swedish system of primary and secondary education underwent a dramatic change. New syllabi were written for every school subject. These outlined in detail areas that should be covered from the first year of primary school to the final year of upper secondary school. In 2012 a similarly dramatic change was initiated in teacher training.

In this article I argue that the combination of these two changes provides a golden opportunity to strengthen the academic, secular, and humanistic study of religions at Swedish universities, but that it also requires reflection. The reforms provide an economic and institutional infrastructure that may benefit both research and education. However, the full utilisation of this new infrastructure will require some rethinking concerning how and why we study religion in the first place, and also how we conceive of the particular 'humanistic' character of our study.

The humanistic study of religions concerns (among other things) historical and contemporary beliefs, practices, and social organisations that are 
connected with human notions of superhuman agents. ${ }^{1}$ The key word here is human. The study ultimately concerns human beings: their actions, their beliefs, and their ways of social organisation; not gods, demons, angels, or devils. The understanding of the term 'humanistic' in this article is for the most part posed against 'theological' studies of religion, where superhuman agents themselves (gods, demons, angels etc.), their (assumed) beliefs, intentions, and actions are the ultimate objects of study.

The article is based on an expansion of the concept 'humanistic' beyond descriptive inventories of the human phenomenon of religion throughout history, systematisation, and labelling of its various expressions (myth, ritual, prayer etc.) and the critical discussions about the aptness of the conceptual apparatuses employed. I believe that the humanistic, as opposed to theological, study of religion has great potential to contribute to an ongoing and genuinely multidisciplinary study of the strange and fascinating species we call Homo sapiens, its coming into existence, and its characteristics. In this, I further claim, lies a new way of conceiving, and as a consequence justifying, the place of religious studies as a compulsory subject in the Swedish school system.

Integrating the humanistic study of religion into this wider academic context means, first, treating religion as essentially human and the rejection (at least in principle) of the notion that phenomena under the umbrella concept of 'religion' are, sui generis, unique, irreducible, and beyond explanation. Second, and perhaps more controversially, it means problematizing a key methodological concept that is often taken for granted in the humanities at large: that cultural phenomena can be explained by reference to entities such as beliefs, needs, feelings, intentions, and strategies of actors that are in themselves irreducible. The presence of such entities is inferred from a Cartesian, dualistically informed, introspection (I have mental and emotional states that I term beliefs, needs, feelings, intentions etc. that explain my actions) combined with observations of the behaviour of others, behaviour that it is assumed is caused by the same type of entities (which makes the reasoning circular). Current research into how the human mind works has shown that introspection concerning the relationship between emotions, mental states, and actions is often quite fallible, and that the mental and emotional states that we term beliefs, strategies, intentions, and feelings are far from sui generis, but rather easily manipulated in quite predicable ways (see e.g. Lewis 2013). A convergence of different disciplines, e.g. linguistics,

1 Note that this is not a definition of "religion'. It is my delimitation of the object of study within the humanistic study of religions. 
computer science, developmental psychology, neuroscience, anthropology, evolutionary biology, and comparative ethology, is slowly, but steadily, moving towards an increasingly comprehensive understanding of what makes humans, as a distinct species, special, and what makes human culture, including religion, possible and likely. My claim is that what we are witnessing in this process is the beginning of a large-scale epistemological exorcism of the humanities that is driving out the cherished Geist from Geisteswissenschaft and moving towards a Wissenschaft, in which the distinction between the humanities and the other sciences is becoming increasingly blurred (see e.g. Slingerland 2008; Wilson 1998). This development does not render the humanities and the humanistic study of religion redundant. On the contrary, mapping human culture throughout history, systematising it, probing into its details, making comparisons, pointing to continuity, disruption, and change and to correlations between cultural expressions, social structures, and physical environments is a necessary, indeed indispensable, element of the overall collaborative project. ${ }^{2}$ It is also precisely in this capacity that the humanistic (in the basic sense stated above) study of religion becomes important in relation to religious education in Sweden. RE has the potential to become the school subject that more than any other secures the important task of teaching children about who they are and why.

To strengthen my argument the article will first provide a short outline of the content of the two reforms mentioned above, and briefly contrast the current situation to situations before these reforms. This can be seen as a contextualisation that may afford an explanation of the somewhat peculiar place that RE has in the Swedish school system. Second, I will turn to the basic claim of the article: that a minor rethinking of the humanistic study of religion in academia and a consequent reform of teacher training at university level will provide a new and fruitful role for RE within the school curriculum. I will refer to a short set of cases as examples. These serve merely as snapshots. As my own scholarly expertise is in the field of Islam, that religion will serve as the basic starting point, highlighting the particular, and currently hotly discussed, case of ISIL, the Islamic State in Syria and the Levant.

The historical contextualisation of RE and the claim that there is a need to reform the academic humanistic study of religion in Sweden in light of new research can be seen as both properly academically descriptive and critically analytical tasks. However, advocating change in the purpose and

2 For a book-length argument in line with this, but specifically relating to anthropology, see Bloch 2012. 
objectives of RE in Swedish schools is a basically normative endeavour, concerning less how things are and more how they should be. This is an approach to the subject with which I am neither familiar nor comfortable. Such a normative perspective, however, is less problematic if considered in the context of the subfield of the (Swedish) study of religions in which this article could be categorised, that of the didactics of religion. The didactics of religion concern themselves with the questions of 'what', 'how', and 'why' in relation to RE as taught in schools. These questions may have a descriptive and analytical focus: what is being taught, how is it being taught, and why are these choices and not others made? ${ }^{3}$ However, there are also quite a number of examples of academic work that frame these questions in a normative way: what should be taught, how should it be taught, and why should these choices (and not others) be made ${ }^{4}$ The basic argument of this article, as stated above, is rooted in the 'why' question and has a clear 'should' aspect, which is related to an ambition to contribute to the strengthening of the position of the humanistic study of religions in Swedish academia. Answers to both the 'what' and 'how' questions follow from this.

\section{The reforms}

\section{New teacher training}

The 2012 reforms in teacher training at Swedish universities had two overarching objectives: to increase subject knowledge among prospective teachers; and to increase teaching competence in order to transform that knowledge into a teaching practice that in turn may increase the pupils' knowledge. The important shift here was from an approach focusing on general teacher-student relations and pedagogy to one focusing on the knowledge and knowledge transmission specific to the subject.

In reference to changes in Swedish society and to international events the government bill concerning the future of teacher training presented to parliament on 4th January 2010 points to a need for both width and depth in teachers' knowledge (Sveriges regering, 8). Teachers should have profound insight into the subjects they teach (Sveriges regering, 9). This is particularly important for teachers at lower and upper secondary schools

3 For an excellent example of this, see Berglund 2010.

4 I contend that the bulk of what is published within the field has this normative character: see e.g. Olivestam 2006; Falkevall (ed.) 2013; Löfstedt (ed.) 2011. 
(pupils aged 13-18), for which a more subject-focused education for future teachers (compared with the lower levels of primary school [pupils aged 6-12]) is required (Sveriges regering, 24). Furthermore, the bill stresses the importance of a close relationship between upper secondary schools and universities, both to facilitate the transition between school and university and to make teachers experts in their fields (Sveriges regering, 26).

One of the main changes introduced for future lower and upper secondary teachers was therefore to increase the time dedicated to individual subjects at the expense of general pedagogy, previously termed the 'field of general education' (Allmänt utbildningsområde, AUO). This was replaced by a more academic cluster of centrally defined courses termed the 'core of educational science' (Utbildningsvetenskaplig kärna, UVK), and was reduced by a third (from eighteen months to a year), while the time devoted to subject study was increased (Sveriges regering, 35-7).

Prospective upper secondary teachers (the first of whom will graduate in the spring of 2016) will on completion have attained master's level in their primary teaching subject and bachelor's level in their secondary subject. The bill also stresses that at least half the teaching practice should be subjectspecific and take place under the formal auspices of individual subjects (Sveriges regering, 25). The reforms thus contain a clear strengthening of the academic element of teacher training.

However, the Ministry of Education had more thorough plans for reform. As the new teacher training programme was launched, all higher education institutions, without exception, had to reapply for a licence to issue teaching degrees. Every institution had to compile a thorough inventory of actual competences, as well as descriptions of how the new training was to be organised. A selection process followed, which was clearly not for show. In the field of RE several Swedish institutions with university status did not receive the licences for which they had applied, and among them was one of the most prestigious. They could not demonstrate conclusively that their training met the new standards. On the other hand, several of the smaller university colleges, often with differently structured training, passed the test. It is possible - at least in some cases where numbers of both teachers and students were very small - that this was closely connected to the fact that these smaller institutions, although short of resources, offered training whose structure was in tune with the other aspect of RE in Sweden that needs to be considered: the new syllabi of 2011. 


\section{New syllabi in a historical perspective}

The reforms of teacher training introduced by the government in 2012 did not in themselves specify the content of courses, either in the study of religions at university level or in any other subject relevant to teacher training. However, it is possible that when universities were evaluated at least some consideration was given to how training matched the actual demands of the school subject (which was in line with the intentions expressed in the 2010 bill). To substantiate this latter claim a closer look at these syllabi and a very brief historical contextualisation are merited. ${ }^{5}$

It may appear strange that religious education should be a compulsory subject at all levels in Swedish schools, given that Sweden is sometimes described as one of the world's most secularised countries, has the highest percentage of professed atheists, and the lowest who state that religion is an important part of their lives. ${ }^{6}$ Part of the explanation is historical. RE grew out of an earlier confessional education with a history dating to the introduction of the compulsory school system in 1842, and the central role played by the state religion of Evangelical Lutheranism in education and in nurturing obedient subjects of the Swedish crown. However, this historical foundation is insufficient as an explanation. Religious teaching has changed enormously since 1842, and its evolution has clearly been connected with social change. The place of RE in the curriculum has been challenged many times, especially in the last fifty years, but, although it has been pushed further and further from the core, it has persisted. It is my contention that one of the underlying reasons is that the subject's proponents, in their changing ideas about its role and purpose, have been successful in continuously adapting the subject to the prevailing Zeitgeist.

When the dominance of the state church was challenged by the emergence of other Christian denominations at the beginning of the twentieth century, the subject ceased to focus on the rote learning of Martin Luther's Small Catechism and biblical history, and adopted a more general Christian focus stressing the teachings of Jesus. This was formalised with a name change in 1919, when the teaching of the catechism was abolished. The main objective of teaching remained the moulding of good, loyal Christians (even if no longer necessarily good Lutherans). However, with Sweden's

5 The following outline of the historical development is limited. For a more comprehensive presentation, see Hartman 2011 and Hartman 1994.

6 The claim that Sweden is the most secularised or atheist country in the world may be challenged on several accounts. I will not do that here though, as it would lead in the wrong direction. For a new, book-length, critical discussion, see Thurfjell 2015. 
rapid economic and social modernisation in the twentieth century, even this approach to teaching was challenged, as was the authority of the church in politics in general and in education in particular. A radical and important shift came in the early 1960s (in spite of the fact that the name of the subject remained 'Christianity' until 1969, when it was changed to 'religious education' [religionskunskap]). There was (in theory, but perhaps not in practice) a clean break with the confessional and moulding features of religious teaching, and a new direction was taken towards both widening the scope of its content (teaching was now expected to cover not only Christianity, but also other religions and non-religious worldviews), and towards meeting demands from a public intellectual elite (often critical of religion) that teaching should be religiously neutral. Hence, religious teaching became teaching about religion. This perspective was further challenged in the late 1960s when another factor came into play: a new pedagogical tradition that was critical of teacher-centred education. This affected RE. The ideal of neutral teaching was challenged, as well as the notion that the primary role of RE was to provide facts about religion. Instead - at least in the general discourse, but also in the content of the new syllabi produced in 1969 and 1980 - there was what could be seen as a return to the subject's former moulding character. Fact-oriented RE - on the basis of some surveys of pupils' attitudes (the weight of which informed the shift in thinking about the role of education in general) - was judged to be non-engaging and uninteresting. The role of RE was now to provide pupils with tools for the construction of their own personal worldviews and identity (religious or not), based on their 'ultimate concerns'. Facts about religious traditions were now largely construed as resources for pupils' personal reflection. There was therefore another name change in 1980: the subject was now called 'Human questions of life and being. Religious education' (Människans frågor inför livet och tillvaron. Religionskunskap). This view of the role and function of RE as an arena for personal worldview construction has been quite influential and remains strong, especially within the academic discipline of the didactics of religion that has already been mentioned. (For examples, see Olivestam 2006, 138-148; Löfstedt 2011a; Falkevall 2013, 27-9.) This is despite the fact that the subject's name was again changed to religious education (Religionskunskap) in 1994.

Yet further social changes were to come that influenced RE. In the 1980s and 1990s, not least as a result of immigration, Sweden was becoming an increasingly multireligious society, and a new role for RE emerged as a subject in which tolerance and understanding of people with diverging beliefs 
and practices could be developed. This notion that RE, in addressing diverse religious traditions, should provide a basis for interpersonal understanding and social tolerance - like the notion of its role as character moulding and identity building in general - is of continuing influence on the subject. ${ }^{7}$

\section{The 2011 syllabi}

What then of the new syllabi? They are much more detailed in outlining both the purpose of the subject and the goals and specific content than previously, and I cannot go into all the details here. However, there are some important similarities and differences - again mirroring changes in society and the Zeitgeist-in relation to previous syllabi that should be highlighted, because they are of immediate relevance for this article's overall claim.

First, although they differ in structure, there are similarities in content between the new syllabi and their predecessors. However, it is the differences that are most relevant. The new syllabi are the most comprehensive to date. They move away somewhat from the notion of RE's instrumental role in pupils' development of their own worldviews that has been so dominant in the last four decades, and in that sense constitute something of a return to a more facts-oriented approach. Religious traditions and non-religious worldviews are firmly established as objects of study in themselves. This is especially seen in the place given to the concept of 'life questions' (livsfrågor) that was central to the pupil-oriented pedagogy of the 1970s. ${ }^{8}$ In the latter pupils' own life questions formed the starting point in determining which religious traditions and non-religious alternatives should be taught. In the 2011 lower secondary syllabus the life questions still constitute part of what needs to be covered, but are no longer central. More importantly, they are seen as general human life questions to be treated as historically relevant, i.e. they are not limited to whatever existential questions pupils happen to have as they are being taught (Skolverket 2011b).

Another important change is that the new syllabi have a strong focus on religion as a human and cultural phenomenon. This is a departure from a limited theological and dogmatic focus on different religious traditions, and a move towards the study of everyday beliefs, narratives, practices,

7 For a discussion on teaching practice related to this goal, see Liljefors-Persson 2011. Historian of religion Bodil Liljefors-Persson bases her article on the pedagogic model "Abrahams barn' (Children of Abraham) with a narrative of Abraham as the common religious ancestor of Christianity, Judaism, and Islam. For a critique of this model, see Löfstedt 2014.

8 For a recent overview of the concept, see Löfstedt 2011a. 
and experiences, from the level of experts to 'ordinary people'. This is an indication of the cultural turn within the academic study of religion (see e.g. Slone 2004, 26-8) Although the syllabi still focus on dogma, there is now an explicit stress on diversity, change, and conflict within religious traditions.

The comparative perspective is also stressed. In the primary and lower secondary syllabi the focus is on a comparison between the specific religious traditions which must be covered (not excluding the possibility of also covering others), as well as on the themes of the comparisons that should be made, e.g. festivals, rituals, narratives, symbols, artefacts, and historical development. In early drafts of the syllabi Christianity was placed alongside other traditions. Through the personal intervention of the then Minister of Education, Jan Björklund, however, Christianity was given a special place in the text, but with no substantive consequence. For example, Björklund changed the text specifying 'Rituals, religiously motivated rules of living, holy places and spaces in Christianity, Islam, Judaism, Hinduism, and Buddhism' to 'Rituals, religiously motivated rules of living, holy places and spaces in Christianity and in the other world religions: Islam, Judaism, Hinduism, and Buddhism'. The change was symbolic and political, and was probably a response to protests from representatives of the small Christian Democratic Party in the ruling coalition that Christianity was not being given a privileged place in the syllabi. ${ }^{9}$

In general one could say that the 2011 syllabi are increasingly focused on human beings, their beliefs, practices, and ways of social organisation in a manner that is more general and less individualistic, more historical, less ideological, more cultural, and definitely more comparative than previous syllabi. The scope is less national and more global, and there is an explicit ambition, at least at upper secondary level, not only to describe but also to understand and explain both diversity and commonality in different forms of human expression. This forms the starting point for the following, more normative, part of this article.

\section{RE and the humanities}

Throughout the twentieth century, since the abolition of confessional Lutheran education, there has been a recurring challenge to justify RE's retention as a compulsory school subject. The challenge remains today. The present article, and its basic claim, should be seen in this light. To repeat,

9 For a short overview of the politically charged process of constructing the syllabus for primary and lower secondary school in 2010, see Svensson 2011. 
the claim is that no other compulsory school subject offers a similar opportunity to probe into what it has meant and means to be human. RE has the potential to become the setting in which pupils are allowed to explore the basic shared human capacities and proclivities for culture, for morality, for imagination, for creativity, for cooperation, and for conflict. While there are other school subjects that might cater for some of these aspects, none has a similarly comprehensive scope. This is clearly acknowledged in the 2011 primary and lower secondary syllabus, where one of the purposes of the subject is spelled out as to 'provide resources for them [the pupils] to be able to interpret cultural expressions connected to religious traditions' (Skolverket 2011a). Here, a narrow concept of 'culture', involving art, literature, music, drama, etc., is intended. (I know, because I was involved in its formulation.) If we exclude the last century or so from consideration, the majority of such cultural expressions are religious in one way or the other.

The remainder of this article provides some examples of how this perceived potential for RE can be effected in teaching, by highlighting explicit topics in the syllabi and in connection with them indicate how contemporary research on human beings as a cultural and religious species can provide ample opportunities for a fruitful comparative approach to religion, between religious cultures, and between religious culture and other elements of human culture. An important aspect to remember is that the syllabi, and especially the upper secondary syllabus, place great emphasis on training the pupils' ability to analyse religious phenomena. To reach the higher grades pupils must be able to perform quite advanced analysis, within a comparative framework, and reach conclusions of a general character. ${ }^{10}$ This, I claim, cannot be done without theory.

\section{Possible focus areas - examples}

\section{Human imagination and the construction of alternative worlds}

The syllabi are progressive in the sense that they presuppose that areas covered at earlier stages will provide the foundation for later elaboration. Religious narratives such as myths and legends are therefore covered before lower and upper secondary school. However, the task of critically analysing

10 Note here particularly the parts of the syllabi that outline criteria for different grades (kunskapskrav). For achieving the higher grades, comparison, analysis, and generalising conclusions are necessary. 
these narratives and their role in society can be said to rest largely in these latter stages. What then might a humanistic contribution, as defined above, entail for such an analysis? Let me offer an example.

The proponents of the Islamic State in Syria and the Levant have been quite clear concerning their political ambitions. The movement has repeatedly published (with modifications) their vision of a future world in the form of a map that outlines the boundaries and the structure of an imagined territory under a unitary Islamic jurisdiction, the Caliphate. At first glance, and even in the rhetoric, this is connected with historical precedent. A closer examination, however, reveals that this cannot be the case. The (imagined) Caliphate under ISIL is a selective compilation of several distinct and historical empires with different boundaries. It is a blending of historical facts, an imagining of an ideal rule of harmony under a strong leader (which and who probably never existed in practice), and a projection of that construction into the future. This is, of course, nothing new in the history of religions. In this respect there is an abundance of imaginary worlds: worlds that were (golden ages), worlds that will be (paradises, utopias), parallel worlds different from the ones in which they themselves live (the realm of the gods, spirits, ancestors etc.).

It can certainly be fascinating to describe imaginary worlds or diverse religious traditions, to compare, systematise, categorise, and label them. But other questions may be posed, which I claim are relevant in another sense, even for those not particularly interested in the content of these worlds as such. There is no indication that any other animal besides humans creates them, even in their most rudimentary form. Indeed, the very basic capacity behind these worlds, to mentally represent something that is not present in the here and now, appears rare. Cognitive scientist Peter Gärdenfors speaks of a unique human capacity and proclivity for anticipatory thinking, i.e. planning ahead (Gärdenfors 2008, 85-8), for forming mental simulations of future situations. This capacity has proved a great evolutionary advantage, one of several examples of our species having exploited what psychologist Steven Pinker terms the 'cognitive niche' (Pinker 2010). It is a capacity that humans employ routinely in their everyday lives. It is so 'natural' that we do not even consider it special. And here is the point relating to RE: by highlighting striking examples, like the Caliphate as imagined by ISIL, a way is opened to a more general investigation into the workings of the human imagination in daily life, which is essentially no different. This is an area that, to paraphrase cognitive linguists Gilles Fauconnier and Mark Turner, is increasingly moving from being celebratory of mystery (of imagination) to 
becoming an intriguing scientific investigation (Fauconnier \& Turner 2002). New theories concerning how the human creative imagination works, the rules that govern it, and why it works in this way are being developed and tested (see e.g. Turner 2014). One of the general roles of education is to disseminate advances in human, and more specifically scientific, knowledge. Few, if any, of the subjects in the Swedish curriculum apart from RE can offer a similarly wide-ranging opportunity to do this when it comes to the human imaginative faculties.

Other questions also arise. Although every neurotypical human individual is capable of creating imaginary worlds in her head, very few of these worlds become objects of cultural elaboration, and, as in the case of the ISIL future Caliphate, become established as politically powerful images that attract and inspire action. We can observe and describe emergence, spread, and impact, but how do we explain it? One way is to follow the anthropologist Dan Sperber's lead in his theoretical concept of an 'epidemiology of cultural representations' specifying environmental 'macro-factors' and mind internal 'micro-factors' that influence the process (Sperber 1996, 77-97). The latter's role is especially relevant for a humanistic study, and here comparison is pivotal. The ISIL Caliphate is not the first, nor will it be the last, imaginary world. The history of religions affords evidence of this. In the Swedish classroom, in the context of RE, the evidence can be assessed and discussions can follow concerning what makes certain imaginary historical and contemporary worlds attractive, about human commonalities and differences, and how these can affect cultural distribution. A set of preliminary answers has already been hypothesised and empirically tested: e.g. potentiality for evocation of emotions (Whitehouse 2004), relevance (Boyer 2001), counter-intuitivity (Barrett \& Nyhof 2001), and various other biases in human thought and social learning (Richerson \& Boyd 2005). More will surely emerge in time.

\section{Mentalising}

Although there has been a shift in the 2011 syllabus away from religion as merely a matter of beliefs, and particularly beliefs in gods, and a new focus on other aspects, especially religious behaviour, there is still a place for what can be termed the ideological aspect of religion and dogma. However, even 'belief in gods' can be further explored in the search for a more basic understanding of ourselves as humans. Such beliefs are cultural constructs that reveal another basic, and in its complexity unique, human capacity 
that is, like the capacity for imagination, otherwise hidden because of the 'naturalness' with which we employ it in our everyday lives. However, it has been the focus of much research since it was 'discovered' in the late 1970s (Premack \& Woodruff 1978).

The glossy English language Magazine Dabiq is a channel for ISIL propaganda containing reports of the movement's advance, apocalyptic visions of the future, and articles about the joy of living under Islamic rule in Syria and Iraq. One example of the latter is an interview in issue 7 with Umm Basir, also known as Hayat Boumedienne, suspected accomplice of Amedy Coulibali who was shot dead after attacking a kosher shop in Paris in the spring of 2015, in connection with the attack on the offices of Charlie Hebdo. She tells of her joy at being in ISIL-controlled territory: 'All praise is due to Allah who facilitated the way for me [to come to Syria...] Living in a land where the law of Allah ('azza wa jall) is implemented is something great. I feel at ease now that I have carried out this obligation. All praise is due to Allah. I ask Allah to keep me firm.' (Anonymous 2015, 50) Few people will have any problem understanding the basic meaning of this utterance (although they may resent it). I suggest, however, that even fewer realise that this very understanding rests on a complex mental operation, so complex and costly that few species in the animal kingdom have developed the capacity for it, and none in the elaborate manner found in Homo sapiens. The capacity is for creating advanced mental images of the 'inner worlds' (Gärdenfors 2008, 83-5) of other persons (and even animals, objects, and abstract entities), and using such mental constructs as heuristic 'explanations' for observed events in the surroundings.

'Mentalising' among humans is unique in two respects: first, it can be done at several levels (imagining that other human beings imagine the imagination of yet others, as Umm Basir is imagining the imagination of God). Second, we can imagine the inner worlds of persons (or entities) who are not physically present in the here and now, even of those we have never actually experienced. These two aspects of mentalising, in combination, constitute the backbone of the human 'Machiavellian intelligence' (de Waal \& Morris 1982), a prerequisite for large-scale human social interaction, including such activities as social planning and deception. ${ }^{11}$

$\mathrm{RE}$ is a potential goldmine for exploring this human capacity precisely because the history of religions abounds with cultural examples of it. Indeed, the capacity is a basic prerequisite for such frequently recurring phenomena

11 For a discussion of the evolutionary background, see Gamble et al. 2014. 
as beliefs in invisible gods, ghosts, and ancestors as social actors. ${ }^{12}$ But there are other avenues to tread that relate to pupils' more immediate lifeworlds. Although Sweden is a society that has seen a marked decline in people's active participation in religious activities and engagement in religious collectives, beliefs in non-human actors engaged in world events seem to linger. It is even more noticeable that less personalised entities that affect the individual's life seem still to be very much part of the common imagination (see e.g. Thurfjell 2015). Similarly, while specific notions of heaven and hell may become less relevant, there are still many who ask, 'What happens after we die?' It is possible to explain both these phenomena if the mentalising capacity is taken into account.

As has already been observed, the previous and current RE syllabi have given space for students to reflect on existential life questions. However, no answers are given. The perspective offered in this article also provides no answers, but it suggests a possible answer to why humans pose, and throughout history have posed, life questions in the first place. It is part of who we are. The perhaps most basic question 'What is the meaning of life?' is, as the psychologist Jesse Bering suggests, a by-product of a combination of anticipatory thinking and mentalising - both of which are capacities that have been adaptive in evolutionary terms. The combination results in the recurring notion that things happen (or will happen) for a reason. Human beings have a natural proclivity for this kind of 'teleo-functional reasoning', and the history of religions provides ample evidence for this (Bering 2013, 39-76).

Even more specific life questions may be explored in this way in the classroom. Recent research on the proclivity in human thinking for mindbody dualism, in connection with the way in which a person's notions of her inner world is mentally processed differently than perceptions of her material body, ${ }^{13}$ can, for example, provide fertile ground for a comparative analysis of one of the themes the syllabus explicitly mentions, the life question concerning what happens after death, and why this has been such a recurring theme in history.

12 For a fairly recent, general, and accessible introduction to the role of mentalising in the field of religion, and particularly beliefs in superhuman agents, see Bering 2013. For other introductions, see e.g. Tremlin 2006; McCauley 2011.

13 For a recent review article of research on intuitive dualism that claims it is a pan-human proclivity, see Chudek et al. 2013. For similar claims, see Bloom 2007. 


\section{Cooperation and conflict}

The lower secondary syllabus clearly states that the social roles (plural) of religion should be part of what is taught: 'The teaching shall in a neutral manner shed light upon the role religions can play in society, both in the quest for peace and in conflict, to serve as a tool for social cohesion and as a cause of segregation' (Skolverket 2011a) A similar content is specified for upper secondary school (Skolverket 2011b). Such features of the syllabi can be construed as a direct result of world events in recent decades, and an increased understanding that organised religion, though marginal in Swedish society, is an important factor in understanding and explaining contemporary politics in other parts of the world.

This potential for religion to play an important part in political thinking and action is perhaps most evident, even as I write, in the example of ISIL, which will inevitably need to be addressed in the classroom. Here, I can only hint at a particular theme that may be useful as a starting point and that may lead to a more in-depth probing into more general basic human peculiarities. It is clear that ISIL to a large extent exploits the all too human proclivity for social categorisation and erection of boundaries between 'us' and 'them'. 'Us' are the true Muslims, heeding the will of God as literally expressed in the Qur'an and the Sunna. 'Them' is practically everyone else: Western 'crusaders', Shiite 'apostates', Yazidi 'Satanists', and Peshmerga 'Zionists'. ISIL propaganda is a prime example of how social categories are created and imbued with negative emotive value through association with names and epithets borrowed from an Islamic historical and theological 'pool of resources' (Eickelman \& Piscatory 2004). Internal group identity is marked by the use of objects or other emblems: the style of beard, badges, songs, slogans, particular behaviours, etc. All of this is known in the history of religions. There is nothing new here, and this can easily be highlighted in teaching. We know, from experimental research as well as from natural observation, how important and powerful visible emblems in themselves can be in triggering processes of internal solidarity and external hostility. As an educational resource the example of ISIL and the comparative history of religions can be transposed to students' immediate lifeworld, and thus encourage reflection on common human social-psychological processes.

Human beings are ultra-social, with a unique capacity to form large-scale cooperative units that has been one of the most important factors in the evolutionary history of the species. This feature is shared only with certain insects and naked mole-rats. In the cases of these other animals, however, large-scale cooperation is only done with close relatives. Humans, on the 
other hand, can also have large-scale cooperation with those not related to themselves, provided they are mentally represented as belonging to the same group (narrowly or widely defined). ${ }^{14}$ The way in which diverse phenotypical traits or cultural markers (language, dress, behaviour) are utilised in this process is a basic, but also important, issue to address in teaching as part of a more general moulding of responsible future citizens. It is part of educating critical thinkers. As scanning for potential collaborators and foes is an ongoing, and mostly unconscious, process among humans, the danger of exploitation is immediate.

The Swedish school system has, as an explicitly formulated task, the promotion of the values of social tolerance and solidarity across such otherwise easily exploitable markers as ethnicity, language, and religion. A focus on informing pupils of these cherished values, telling them that they are not allowed to define 'the other' based on these markers, is probably not enough. The very human proclivity to do this, and the abundance of examples of how this human proclivity can be, and has been, exploited at times with horrible results must be addressed if it is to be challenged. RE, with its wealth of empirical cases, provides an excellent starting point, and material more related to pupils' immediate lifeworld can be used as complementary exemplification of the same processes: group formation on the basis of gender, clothing styles, linguistic markers, etc.

\section{Morality and ethics}

Especially since the 1980s it has been stressed that RE should cater to pupils' need for ethical reflection. However, the subject has been, and still is, highly influenced by a traditional view of morality as a consequence of ethical reflection..$^{15}$ This is also evident in the current syllabi. Teaching at lower secondary school should cover: 'Everyday ethical dilemmas. Analysis and argumentation based on ethical models, for example consequence ethics and duty ethics' and 'Conceptions of what constitutes a good life and the good human being connected to ethical reasoning, for example in relation to virtues' (Skolverket 2011a). In the upper secondary syllabus, there is a similar stress on theoretical models and concepts in ethical analysis (Skolverket 2011b). More specifically connected with religion, the lower secondary syllabus mentions 'ethical issues and anthropology [människosyn] in some

14 Research in this area is vast. I recent book by psychologist Joshua Greene provides a good, accessible overview (Greene 2013).

15 For a recent example of this in the didactics of religion, see Löfstedt 2011b. 
religions and worldviews [livsåskådningar]'. The corresponding wording in the upper secondary syllabus is that pupils should 'investigate and analyse ethical issues in relation to Christianity, other religions and worldviews' (Skolverket 2011b). The underlying perspective and view of ethics and morality is clear. The focus on (rational) ethical reasoning as the basis for morality ignores the fact that evidence has been mounting since the 1980s that the relationship between morality and ethics probably happens the other way round. (See e.g. Haidt 2001; Haidt 2012.) Although, of course, human beings engage in ethical reflection, such reflection is more often than not a secondary rationalisation of what, for lack of a better term, may be called a 'gut-feeling'. The importance of this recognition can be illustrated with another example related to ISIL.

Especially since 2015 there has been an increasing public uneasiness in Sweden and other European countries concerning the fact that a number of young Muslims have travelled to Syria to join the ranks of ISIL. 'Radicalisation', its causes and how it can be prevented, has been much to the fore. It is currently estimated that perhaps as many as three hundred young Muslims have left Sweden for Syria. Among them some young women, going not to participate in the fighting, but to marry the fighters. There has been much focus on the men who have travelled. Their engagement with ISIL has been seen as presenting a danger to national security, because they could very well return to Sweden trained for terrorist attacks. Then, of course, there are the various acts of violence they may perform in situ. These concerns are certainly reasonable. But what problems do the young women present?

There has been a longstanding and ongoing public debate in Sweden about the limitations on young women's freedom posed by the so-called 'culture of honour', associated for the most part with Swedes of a Muslim or Middle Eastern background. The problem is that young women of a certain background are not allowed to choose their own partners but are forced to marry someone chosen for them by their parents. They are not in control of their own private lives or sexuality. Why then does it constitute a problem when young women leave Sweden for Syria, often against the explicit wishes of their parents, in search of a relationship with a man they have themselves chosen? Should it not instead be seen as a commendable assertion of independence? What is the moral difference when a young woman chooses a spouse in Sweden, sacrificing her wellbeing and safety in the process, or when she does it in Syria? However, I hypothesise that most outsiders consider the latter young woman's act to be morally wrong, and on a par with the 'male' act of joining the actual fighting. 
Discrepancies such as this could form the starting point for important classroom discussions on ethics and morality, and how these, in accordance with recent research in moral psychology, are intimately tied to intuitive 'gut feelings' that can be explained. There is, for example, an emerging academic discourse concerning what is termed the 'moral foundations theory ${ }^{\prime 16}$. This theory suggests that underlying the diversity of moral rules and the ethical reasoning that serves to justify them is a set of pan-human rudimentary intuitive morals, limited to five oppositions of care/harm, fairness/cheating, loyalty/betrayal, authority/subversion, and sanctity/degradation. A possible sixth is suggested: liberty/oppression. The different foundations are not equally strong in different social and historical contexts, and themselves sometimes come into conflict, resulting in moral dilemmas. The basic claim is that they are all emotionally based and connected with the problem of human cooperation. I shall not address the theory in detail here, but merely note that it may have some explanatory potential for the example above. It would appear that on the basis of the liberty/oppression foundation there would be nothing to object to in the young women's actions. However, I contend that what underlies the negative moral judgement is the foundation of sanctity/degradation, which is ultimately tied to the emotion of disgust. It is not the act of choosing a spouse against the will of the parents that is problematic (the authority and loyalty foundations are generally not that strong in Sweden, especially compared with the liberty foundation). It is the character of the prospective husband and the act of sex inevitably involved in marriage. The thought of someone having sex with an ISIL jihadist is disgusting, and as a consequence is considered morally wrong. The empirical work on the moral foundations theory provides ample examples of how such disgust, particularly connected to sex, is an unconscious and strong determinant in moral judgements. At the same time it is more often than not difficult to justify these judgements rationally.

One of the main advantages of using empirically based moral psychological research in discussing ethics and morality in the context of RE is that it will relieve the subject from endless classroom discussions about ethical dilemmas (e.g. abortion, euthanasia, cloning) that cannot be resolved because different positions rest on different moral foundations that are all equally 'valid' from a phenomenological point of view. Once this is realised, the

16 For a presentation, see Haidt 2012. This theory has received much attention in contemporary research on moral attitudes. A combined search on Google Scholar (2015-03-16) for "moral foundations theory' [within quotation marks to limit the search] and Haidt, and limited to the year 2015, produced 233 results. 
study of ethics and morality can be turned in what I see as a more fruitful direction for the main objective this article proposes for the subject, i.e. learning the basics about what it is to be human. Teaching can help students explore the roots of moral rules that appear to recur over time and space: do not lie, do not cheat, do not kill (those belonging to your own group, at least), do not sleep with your brother/sister, etc., and the way in which these emotively founded rules are, at the level of reflective thought, objectivised as 'the will of God' or 'the laws of society'.

\section{Conclusion}

To repeat: the four suggested focus areas above are merely examples. They might be complemented by several others similarly grounded in the explicit directives of the RE syllabi. The point has not been to specify how a humanistic approach, as defined above, to RE can be effectuated in detail, but to show that it can be.

It can easily be countered that what I propose here as a way of developing RE may just as well be done in other school subjects such as art education, music, literature, or even economics. In a way this is correct. All of these cover aspects of human culture and can all contribute to a better, empirically founded, understanding of what it means to be human, provided they are framed in the same manner as has been done with RE above. There are, however, two important circumstances that have already been mentioned. First, few human phenomena (at least from a historical perspective) encompass such a wide range of human activities as does religion, including activities within the areas mentioned - art, music, literature, and economics. Second, $\mathrm{RE}$, unlike the others (except literature), is a compulsory subject at all levels in primary and secondary education. This means that choosing RE as the subject catering for this particular aspect of educating young people will ensure that all pupils receive exposure to it.

The basic suggestion for RE here is to move from a somewhat limited, but in no way unimportant, descriptive study of religious expressions in history and in the contemporary world, and to make the subject the backbone of a quest to understand human beings as a cultural species. However, if this is to be achieved teachers must be equipped with the relevant tools. This is where the academic, humanistic study of religions at university, and the teaching attached to it, comes in. Such a study needs first to be thoroughly 'humanitised', i.e. religion must be analysed and taught as an entirely human phenomenon. Second, students who aspire to become teachers of RE 
must receive a broad introduction to the various aspects of different religious traditions, but at the same time must also be trained, and inspired, to dig more deeply. They must be provided with the tools to handle the typically childish question 'why', tools that are firmly grounded in what we know, or at the moment think we know, about human beings in general, i.e. theory. If this challenge is to be met, the humanistic study of religions at university level needs to expand its theoretical horizons and consider perspectives of religion developed in anthropology, sociology, psychology, and, yes, even in the natural sciences.

JONAS SVENSSON is Associate Professor in the Study of Religion at the School of Cultural Sciences, Linnæus University, Sweden. E-mail: jonas.svensson@lnu.se

Bibliography

Anonymous

2015 An interview with Umm Basir al-Muhajirah. - Dabiq 7, 50-1

Barrett, Justin. L. \& Melanie A. Nyhof

2001 Spreading Non-Natural Concepts. The Role of Intuitive Conceptual Structures in Memory and Transmission of Cultural Materials. Journal of Cognition and Culture 1(1), 69-100.

\section{Berglund, Jenny}

2010 Teaching Islam. Islamic Religious Education in Sweden. Münster: Waxman

\section{Bering, Jesse}

2013 The God Instinct. The Psychology of Souls, Destiny, and the Meaning of Life. London: Nicholas Brealy Publishing.

\section{Bloch, Maurice}

2012 Anthropology and the Cognitive Challenge. Cambridge: Cambridge University Press.

\section{Bloom, Paul}

2007 Religion is natural - Developmental Science 10(1), 147-51.

\section{Boyer, Pascal}

2001 Religion Explained. The Human Instincts that Fashion Gods, Spirits and Ancestors. London: Vintage.

Chudek, Maciek \& Rita McNamara \& Susan Burch \& Paul Bloom \& Joseph Henrich

2013 Developmental and Cross-Cultural Evidence for Intuitive Dualism. Draft article for Psychological Science. <http://www2.psych. 
ubc.ca/ henrich/pdfs/ChudekEtAl_InutiveDualism_WorkingPaper_June2014.pdf $>$, accessed 27 November 2015.

\section{Eickelman, Dale F. \& James Piscatori}

2004 Muslim politics. Princeton, NJ: Princeton University Press.

Falkevall, Björn (ed.)

2013 Att undervisa i religionskunskap. En ämnesdidaktisk introduktion. Liber: Stockholm.

\section{Fauconnier, Gilles \& Mark Turner}

2002 The Way We Think. Conceptual Blending and the Mind's Hidden Complexities. New York: Basic Books.

Gamble, Clive \& John Gowlett \& Robin I.M. Dunbar

2014 Thinking Big. How the Evolution of Social Life Shaped the Human Mind. London: Thames \& Hudson.

\section{Greene, Joshua David}

2013 Moral Tribes. Emotion, Reason, and the Gap Between Us and Them. New York: Penguin Press.

\section{Gärdenfors, Peter}

2008 The Evolution of Thought. - Peter Gärdenfors \& Annika Wallin (eds.), A Smorgasbord of Cognitive Science, 81-98). Nora: Nya Doxa.

\section{Haidt, Jonathan}

2001 The Emotional Dog and Its Rational Tail. A Social Intuitionist Approach to Moral Judgment. Psychological Review 108(4), pages.

2012 The Righteous Mind. Why Good People are Divided by politics and religion. London: Allen Lane.

\section{Hartman, Sven G.}

1994 Hur religionsämnet formades - Edgar Almén \& Ragnar Furenhed \& Sven G. Hartman (eds.), Att undervisa om religion, livsfrågor och etik $i$ skolan. Texter för lärarutbildning och lärarfortbildning. Linköping: Linköpings universitet.

2011 Perspektiv på skolans religionsundervisning. - Malin Löfstedt (ed.) Religionsdidaktik. Mångfald, livsfrågor och etik i skolan, 19-33. Lund: Studentlitteratur.

\section{Lewis, David}

2013 Impulse. Why We Do What We Do Without Knowing Why We Do It. Cambridge: The Belknap Press of Harvard University Press.

\section{Liljefors-Persson, Bodil}

2011 Abrahams barn - inkluderande undervisning utifrån kreativt samarbete och dialog' - Malin Löfstedt (ed.) Religionsdidaktik. Mångfald, livsfrågor och etik i skolan, 187-200. Lund: Studentlitteratur. 


\section{Löfstedt, Malin (ed.)}

2011 Religionsdidaktik. Mångfald, livsfrågor och etik i skolan. Studentlitteratur: Lund.

\section{Löfstedt, Malin}

2011a Livsfrågor på gott och ont'. - Malin Löfstedt (ed.) Religionsdidaktik. Mångfald, livsfrågor och etik i skolan, 51-64. Lund: Studentlitteratur.

2011b Etik, moral och det goda livet. - Malin Löfstedt (ed.) Religionsdidaktik. Mångfald, livsfrågor och etik i skolan,113-24. Lund: Studentlitteratur.

\section{Löfsted, Torsten}

2014 Abrahams barn. En kritisk reflektion kring ett begrepp - Niklas Ammert \& Ulla Rosén \& Jonas Svensson (eds.) Blickar. Kulturvetenskapliga perspektiv på utbildning, 165-78. Växjö: Linnaeus University Press.

McCauley, Robert N.

2011 Why Religion is Natural and Science is Not. New York: Oxford University Press.

Olivestam, Carl E.

2006 Religionsdidaktik. Om teori, perspektiv och praktik i religionsundervisningen. Liber: Stockholm.

\section{Pinker, Steven}

2010 The Cognitive Niche. Coevolution of Intelligence, Sociality, and Language - Proceedings of the National Academy of Sciences, 107.

\section{Premack, David \& Guy Woodruff}

1978 Does the Chimpanzee Have a Theory of Mind? Behavioral and Brain Sciences 1(4), 515-26.

\section{Sveriges regering}

2010 Bäst $i$ klassen - en ny lärarutbildning. Regeringens proposition 2009/10:89. Sveriges regering. < http://www.regeringen.se/rattsdokument/proposition/2010/02/prop.-20091089/>, accessed 12 November 2015.

\section{Richerson, Peter J. \& Robert Boyd}

2005 Not by Genes Alone. How Culture Transformed Human Evolution. Chicago: University of Chicago Press.

\section{Skolverket}

2011a Kursplan. Religionskunskap. <http://www.skolverket.se/laroplaneramnen-och-kurser/grundskoleutbildning/grundskola/religionskunskap>, accessed 27 November 2015.

2011b Ämne - Religionskunskap. <http://www.skolverket.se/laroplaner-amnen-och-kurser/gymnasieutbildning/gymnasieskola/ rel?tos=gy\&subjectCode=rel $>$, accessed 27 November 2015 . 


\section{Slingerland, Edward}

2008 What Science Offers the Humanities. Integrating Body and Culture. Cambridge: Cambridge University Press.

\section{Slone, D. Jason}

2004 Theological Incorrectness. Why Religious People Believe What They Shouldn't. Oxford: Oxford University Press.

\section{Sperber, Dan}

1996 Explaining Culture. A Naturalistic Approach. Cambridge: Blackwell.

Svensson, Jonas

2011 Religionsvetenskap. Ett kontroversiellt ämne - Grundskoletidningen 3, 6-12.

\section{Thurfjell, David}

2015 Det gudlösa folket. De postkristna svenskarna och religionen. Stockholm: Molin \& Sorgenfrei.

\section{Tremlin, Todd}

2006 Minds and Gods. The Cognitive Foundations of Religion. Oxford: Oxford University Press.

Turner, Mark

2014 The Origin of Ideas. Blending, Creativity, and the Human Spark.

de Waal, Frans \& Desmond Morris

1982 Chimpanzee Politics. Power and Sex Among Apes. London: Cape.

Whitehouse, Harvey

2004 Modes of Religiosity. A Cognitive Theory of Religious Transmission. Walnut Creek: AltaMira Press.

Wilson, Edward O.

1998 Consilience. The Unity of Knowledge. London: Abacus. 
